\title{
Chinese TEFL Teachers' Conceptions of Writing: A Partial Credit Model Analysis
}

\author{
Yunjun Kong \\ Doctoral School of Education, University of Szeged, Szeged, Hungary; \\ School of Foreign Languages, Chongqing Three Gorges University, \\ Chongqing, China
}

doi: 10.19044/ejes.v4no4a3 URL:http://dx.doi.org/10.19044/ejes.v4no4a3

\begin{abstract}
This study aimed to examine Chinese TEFL (teaching English as a foreign language) teachers' conceptions of writing, in particular, to find out their agreeability with multifaceted concepts of writing, multi-functions of writing, facilitators to the development of writing, and the basis of good writing. A questionnaire containing natures, functions, and development of writing, and text features of good writing was developed to collect data online; items had 5-point Likert scales. 490 (female 76.3\%) participants were engaged in the sample. Partial credit model was used to analyze participants' agreeability with these constructs concerned with conceptions of writing. Results show that participants generally tend to agree more with the transfer effect of reading activities in facilitating the development of writing as well as the contribution of vocabulary to good texts. However, results also indicate that numerous participants ignore the importance of the length and punctuations of a text, and doubt the communicative function of writing. Participants' specific agreeability with individual construct was also presented and discussed. Findings show that a Rasch Measurement effectively identifies participants' agreeability with conceptions of writing.
\end{abstract}

Keywords: EFL writing, teachers' conceptions, PCM, Chinese TEFL teachers.

\section{Introduction}

In the educational system, it has been widely approved that teachers' professional knowledge directs the effectiveness of instruction and impacts student achievement. According to Schulman, pedagogical content knowledge is the key issue of the teacher knowledge base for teaching (Shulman, 1987). Its constituent element, subject matter knowledge, referring to what teachers know, is the core and prerequisite component of teacher knowledge base. In 
teaching writing in EFL (English as a foreign language) contexts, however, limited information is known about teachers' knowledge of writing (Lee, 2010). In the past few years, a variety of studies emerged in responding to Hirvela and Belcher's (2007) advocacy of more attention to writing teachers' preparation and development. These studies encompass several research themes: Writing teacher education and training (e.g., Crutchfield, 2015; Ene \& Mitrea, 2013; Lee, 2010; Lee, 2013), teachers' beliefs and practice in writing instruction (e.g., Ferede, Melese, \& Tefera, 2012; Fu \& Matoush, 2012; Khanalizadeh \& Allami, 2012; Koros, Indoshi, \& Okwach, 2013); Melketo, 2012; Yang \& Gao, 2013; Yang, 2015), and other teaching behaviours (e.g., Farrell, 2006; Min, 2013). However, there still seems to be a paucity of research on teachers' knowledge base of writing. In order to address this issue, the current study used the case of Chinese context to explore how TEFL teachers understand writing. Specifically, this paper uses a questionnaire aligned with Rasch Measurement Theory to examine Chinese TEFL teachers' conceptions of writing, aiming to find out their agreeability with multifaceted concepts of writing, multi-functions of writing, facilitators to the development of writing, and the basis of good writing. Therefore, the research questions guiding this study are:

- What is the reliability of the questionnaire?

- What is the general distribution of participants' overall attitudes regarding conceptions of writing?

- What effect does gender have on teachers' conceptions?

- What effect does school type have on teachers' conceptions?

- What effect does school level have on teachers' conceptions?

- What effect does school location have on teachers' conceptions?

\section{Theoretical Background}

Both learning and teaching writing in an EFL context are complex and challenging. A synthesis of literature helps with understanding comprehensively the research consensus on writing and recent studies on writing teachers' knowledge. In this section, a discussion about writing and teachers' learning about writing will be conducted.

\section{Research consensus on writing}

In studies of writing, a great deal of research has defined writing as linguistic, cognitive, and sociocultural act. Gelb (1963) in his long immensely cited book A Study of Writing defined writing as "a system of human intercommunication by means of conventionally visible marks" (p. 12). This concept clarifies the communicative tool of writing with its linguistic, social and cultural nature. Decades later, Coulmas (1996) regarded writing as product-focused or text-oriented, considering writing as the ultimate and 
perpetual product of written text or discourse. It is commonly believed that the successful writing is an interaction between the writer, the written text, and the audiences (Osterholm, 1986). Therefore, writing also involves the mental process in which the writer expresses ideas in text for addressing readers. Hyland (2015) perceived writing as linguistic product that a written text is logically organized with its coherent utterance of language and grammar for specific meaning-making. Accordingly, effective writing requires the mastery of knowledge of orthography, morphology, and syntax.

Undoubtedly, writers play the key role in achieving goals of constructing good texts and addressing specific audiences. Therefore, many studies have attached importance to writing activity as a cognitive process. For a long period and even till now, the most influential model of the writing process was coined by Flower and Hayes (1981). Their model gave a whole picture of the recursive process of writing: purpose, goals, audience, generating and translating ideas, evaluating and revising texts. As a selfimprovement of the model, Hayes (1996) added environmental and personal factors and emphasized motivation, cognition, and working and long-term memory in writing. Afterward, a large quantity of research has pursued the cognitive processes of writing, targeting phase-focused writing strategies. For example, Tankó (2005) treated the complex writing activity as a recursive process: prewriting, writing and reviewing.

Apart from the individual and interactional understanding of writing, research has also shed light on writing from perspectives of social and cultural aspects. Hyland (2002) claimed that writing "expresses a culturally recognized purpose, reflects a particular kind of relationship and acknowledges an engagement in a given community" (p. 48). Therefore, writing is "socially and culturally shaped and individually and socially purposeful" (Sperling, 1996, p. $55)$.

In general, the research community has reached a consensus on writing that learners and instructors need to bear in mind that writing involves linguistic, cognitive, social, and cultural aspects for particular communicative purposes in a specific context.

\section{The Rasch Model}

The Rasch model was named after the Danish mathematician Georg Rasch (Rasch, 1960). The model shows what should be expected in responses to items if the measurement is to be achieved. For the Rasch model, dichotomous (Rasch, 1960) and polytomous (Andrich, 1978) versions are available. The rating scale model (Andrich, 1978; Wright \& Masters, 1982) and the partial credit model (Masters, 1982; Wright \& Masters, 1982) are extensions to Rasch's simple logistic model and are suitable for use when items are scored polytomous. The rating scale model was initially developed by 
Andrich for use with Likert-style items, while Master's extension of the rating scale model to the partial credit model was undertaken to facilitate the analysis of cognitive items that are scored into more than two ordered categories. The Rasch Model considers the fit of data and model as the precondition, putting items and individual ability or attitudes on the same scale, avoids the dependence of samples and measurement in tradition assessment so that it provides more objective and reliable information in its measurement. It measures respondents' latent traits in their responses to items, such as participants' ability, attitudes, interest, values, etc.

\section{Methodology}

\section{Instrument}

In order to address the research questions, a questionnaire was used to collect data. The questionnaire was literature-based and self-developed. It has 26 items with 5-point Likert scales (strongly disagree, disagree, uncertain, agree, strongly agree), targeting multi-faceted concepts of writing (4 items), functions of writing (6 items), development of writing (4 items), and basic components for good writing (12 items). Demographic information was also included, e.g., gender, school type, school level, and school location.

\section{Participants}

Due to the exploratory research of the current study, convenience and snowball sampling were used. In total, 490 Chinese TEFL teachers participated in this survey, $23.7 \%$ of them are male, and $76.3 \%$ are female; $89.8 \%$ are teaching in public school, $10.2 \%$ in private schools; $13.3 \%$ work in primary schools, $39.4 \%$ in junior schools, and $47.3 \%$ in senior schools; $17.1 \%$ teach in provincial capital cities, $29 \%$ in cities, $43 \%$ in a county or town, and 10.6 in villages. Participant's work experience range from one year to 36 years $(\mathrm{M}=11.66, \mathrm{SD}=8.31)$.

\section{Procedures}

The questionnaire was administered online on a Chinese platform which is easily accessible. The data collection started in early and ended by the end of January 2017. Then, all data was downloaded, recoded, and transformed into SPSS 24. Relevant data was cleaned and recoded into the dat file for analysis in ConQuest. Based on the research questions, numerous analyses were conducted, and corresponding results are presented in the next section. 


\section{Analysis and Results}

\section{Frequency of responses distribution}

Participants' responses to each construct of the questionnaire are presented respectively in Table $1,2,3$, and 4 . Also, the reliability of each construct is shown below the corresponding table.

Table 1. Category response frequency distributions for Items 1 to 4 of multifaceted concepts of writing

\begin{tabular}{lllllll}
\hline Item statement & & category & category & category & category & category \\
& & & 2 & 3 & 4 & 5 \\
& & SD & D & U & A & SA \\
\hline $\begin{array}{l}\text { 1. Writing is a linguistic } \\
\text { activity }\end{array}$ & 14 & 4 & 5 & 249 & 218 \\
$\begin{array}{l}\text { 2. Writing is a cognitive } \\
\text { activity }\end{array}$ & 8 & 9 & 32 & 264 & 177 \\
$\begin{array}{l}\text { 3. Writing is a social activity } \\
\text { 4. }\end{array}$ & 10 & 26 & 77 & 244 & 133 \\
$\begin{array}{l}\text { Writing is a cultural } \\
\text { activity }\end{array}$ & 10 & 8 & 24 & 241 & 207 \\
\hline
\end{tabular}

Note: $S D=$ Strongly disagree, $D=$ Disagree, $U=$ Uncertain, $A=$ Agree, $S A=$ Strongly agree; reliability, Cronbach's Alpha $=.872$ (4 items)

Table 2. Category response frequency distributions for Items 1 to 6 of functions of writing

\begin{tabular}{llllll}
\hline Item statement & $\begin{array}{l}\text { category 1 } \\
\text { SD }\end{array}$ & $\begin{array}{l}\text { category } \\
2\end{array}$ & $\begin{array}{l}\text { category } \\
3\end{array}$ & $\begin{array}{l}\text { category } \\
4\end{array}$ & $\begin{array}{l}\text { category } \\
5\end{array}$ \\
& & D & U & A & SA \\
\hline $\begin{array}{l}\text { 1. Writing is tool for } \\
\text { thinking }\end{array}$ & 10 & 5 & 14 & 240 & 221 \\
$\begin{array}{l}\text { 2. Writing is a tool for } \\
\text { communication }\end{array}$ & 11 & 10 & 7 & 228 & 234 \\
$\begin{array}{l}\text { 3. Writing is creation } \\
\text { 4. Writing is addressing }\end{array}$ & 12 & 6 & 7 & 198 & 267 \\
$\begin{array}{l}\text { specific audiences } \\
\text { Writing is for proving }\end{array}$ & 12 & 69 & 92 & 188 & 130 \\
$\begin{array}{l}\text { students' knowledge at } \\
\text { exams }\end{array}$ & 15 & 35 & 239 & 189 \\
6. Writing is of \\
$\begin{array}{l}\text { importance in one's } \\
\text { career }\end{array}$
\end{tabular}

Note: $S D=$ Strongly disagree, $D=$ Disagree, $U=$ Uncertain, $A=$ Agree, $S A=$ Strongly agree; reliability, Cronbach's Alpha $=.869$ (6 items) 
Table 3. Category response frequency distributions for Items 1 to 4 of development of

\begin{tabular}{|c|c|c|c|c|c|}
\hline Item statement & $\begin{array}{l}\text { category } \\
1 \\
\text { SD }\end{array}$ & $\begin{array}{l}\text { category } \\
2 \\
\text { D }\end{array}$ & $\begin{array}{l}\text { category } \\
3 \\
\mathrm{U}\end{array}$ & $\begin{array}{l}\text { category } \\
4 \\
\text { A }\end{array}$ & $\begin{array}{l}\text { category } 5 \\
\text { SA }\end{array}$ \\
\hline $\begin{array}{l}\text { 1. Engagement in } \\
\text { speaking facilitates } \\
\text { writing }\end{array}$ & 12 & 8 & 38 & 243 & 189 \\
\hline $\begin{array}{l}\text { 2. Engagement in } \\
\text { reading facilitates } \\
\text { writing }\end{array}$ & 11 & 3 & 5 & 168 & 303 \\
\hline $\begin{array}{l}\text { 3. Engagement in writing } \\
\text { activities facilitates } \\
\text { writing }\end{array}$ & 10 & 3 & 21 & 225 & 231 \\
\hline $\begin{array}{l}\text { 4. Students learn to write } \\
\text { when they are taught } \\
\text { to }\end{array}$ & 9 & 7 & 22 & 266 & 186 \\
\hline
\end{tabular}

Note: $S D=$ Strongly disagree, $D=$ Disagree, $U=$ Uncertain, $A=$ Agree, $S A=$ Strongly agree; reliability, Cronbach's Alpha $=.903$ (4 items)

Table 4. Category response frequency distributions for Items 1 to 12 of basis of good writing

\begin{tabular}{|c|c|c|c|c|c|c|}
\hline \multicolumn{2}{|l|}{ Item statement } & & $\begin{array}{l}\text { category } 2 \\
\text { D }\end{array}$ & $\begin{array}{l}\text { category } 3 \\
\mathrm{U}\end{array}$ & $\begin{array}{l}\text { category } 4 \\
\text { A }\end{array}$ & \multirow{2}{*}{$\begin{array}{l}\text { category } 5 \\
\text { SA } \\
278\end{array}$} \\
\hline \multicolumn{2}{|l|}{ 1. Vocabulary } & $\begin{array}{l}\text { category } 1 \\
\text { SD } \\
4\end{array}$ & 3 & 7 & 198 & \\
\hline \multicolumn{2}{|l|}{ 2. Grammar } & \multirow{2}{*}{$\begin{array}{l}3 \\
5\end{array}$} & 12 & 33 & 265 & 177 \\
\hline \multicolumn{2}{|l|}{ 3. Semantics } & & 3 & 18 & 227 & 237 \\
\hline \multicolumn{2}{|l|}{ 4. Content } & 4 & 4 & 17 & 189 & 276 \\
\hline \multicolumn{2}{|l|}{ 5. Style of language } & 5 & 20 & 62 & 257 & 146 \\
\hline \multicolumn{2}{|l|}{ 6. Cohesive devices } & 3 & 11 & 61 & 281 & 134 \\
\hline \multicolumn{2}{|c|}{$\begin{array}{l}\text { 7. Structure of a } \\
\text { paragraph }\end{array}$} & 3 & 10 & 59 & 280 & 138 \\
\hline 8. Structure of a text & & 4 & 7 & 55 & 263 & 161 \\
\hline \multicolumn{2}{|l|}{ 9. Length of a text } & 8 & 70 & 141 & 206 & 65 \\
\hline \multicolumn{2}{|l|}{ 10. Punctuation } & 7 & 37 & 146 & 218 & 82 \\
\hline \multicolumn{2}{|l|}{ 11. Spelling } & 4 & 16 & 52 & 234 & 184 \\
\hline \multicolumn{2}{|l|}{ 12. Handwriting } & 3 & 16 & 59 & 226 & 186 \\
\hline
\end{tabular}

Note: $S D=$ Strongly disagree, $D=$ Disagree, $U=$ Uncertain, $A=$ Agree, $S A=$ Strongly agree; reliability, Cronbach's Alpha $=.915$ (12 items)

Table 1 to 4 respectively shows that there are responses to each scale of the questionnaire with a high reliability on each construct (the Cronbach's Alpha value ranging from .869 to .915). Namely, distribution of responses to each category with various frequencies and the high reliability of the questionnaire embed a basis for Rasch measurement.

\section{Choice of model: RSM or PCM}

In the current study, the questionnaire has a 5-point Likert scale for responses, which generates polytomous data which can be analyzed using 
either the Masters Partial Credit Model (PCM) (Masters, 1982) or the Andrich Rating Scale Model (RSM) (Andrich, 1978). In the RSM it is assumed that the distances between adjacent response categories within items are unequal, but all items share the same unequal distribution of distances between response categories. In the PCM the distances between adjacent categories within items are not equal and the distances between response categories are unique for each item. Therefore, a comparison will be conducted in the following in order to elicit the model fits better in answering the research questions.

\section{Multifaceted concepts of writing}

To compare the fit of the two models to the construct of multifaceted concepts of writing, a formal statistical test of the relevant fit of these models can be undertaken by comparing the deviance of the two models. It is noted that the rating scale model deviance (3340.518) is 58.56 greater than the deviance for the partial credit model (3281.961). Also, the rating scale model has used eight parameters, and the partial credit model has used 17 parameters, thus, the latter has nine more parameters. When this is compared to a chisquared distribution with 9 degrees of freedom (16.919), this value is significant and it can be concluded that the fit of the partial credit model is significantly better than the fit of the rating scale model.

\section{Multi-functions of writing}

Likewise, on the construct of multi-functions of writing, it is found that the Deviance for RSM is 5438.986 with a total number of estimated parameters 10, and the Deviance for PCM is 5321.173 with a total number of estimated parameters 25 , therefore, the difference of deviance (117) between RSM and PCM is greater than the chi-squared value $\mathrm{x}_{(25-10=15)^{2}}=24.996$; PCM fits better.

\section{Development of writing}

On the construct of development of writing, RSM: Final Deviance: 2904.821, Total number of estimated parameters: 8; PCM: Final Deviance:2869.488, Total number of estimated parameters: $17, \mathrm{df}=17-8=15$, $\mathrm{X}_{(9)}{ }^{2}=16.919$, the difference of deviance between RSM and PCM is 2904.821$2869.488 \approx 35>16.919$, therefore, PCM fits better.

\section{Basis of good writing}

Similarly, on the construct of basis of good writing, RSM: Final Deviance: 10181.378, Total number of estimated parameters: 16; PCM: Final Deviance: 10083.983, Total number of estimated parameters: 49, df=49$16=33, \mathrm{x}_{(33)}{ }^{2}=47.400$, the difference of deviance between RSM and PCM is $10181.378-10083.983 \approx 98>47.400$, therefore, PCM fits better. 
In conclusion, PCM fits better on all constructs. Therefore, the PCM will be used to analyze the data in the following section.

\section{General distribution of participants' agreeability with four constructs}

The response model parameter estimates for the Partial Credit Model to the conceptions of writing is shown in figure 1 (1) and figure 1 (2).

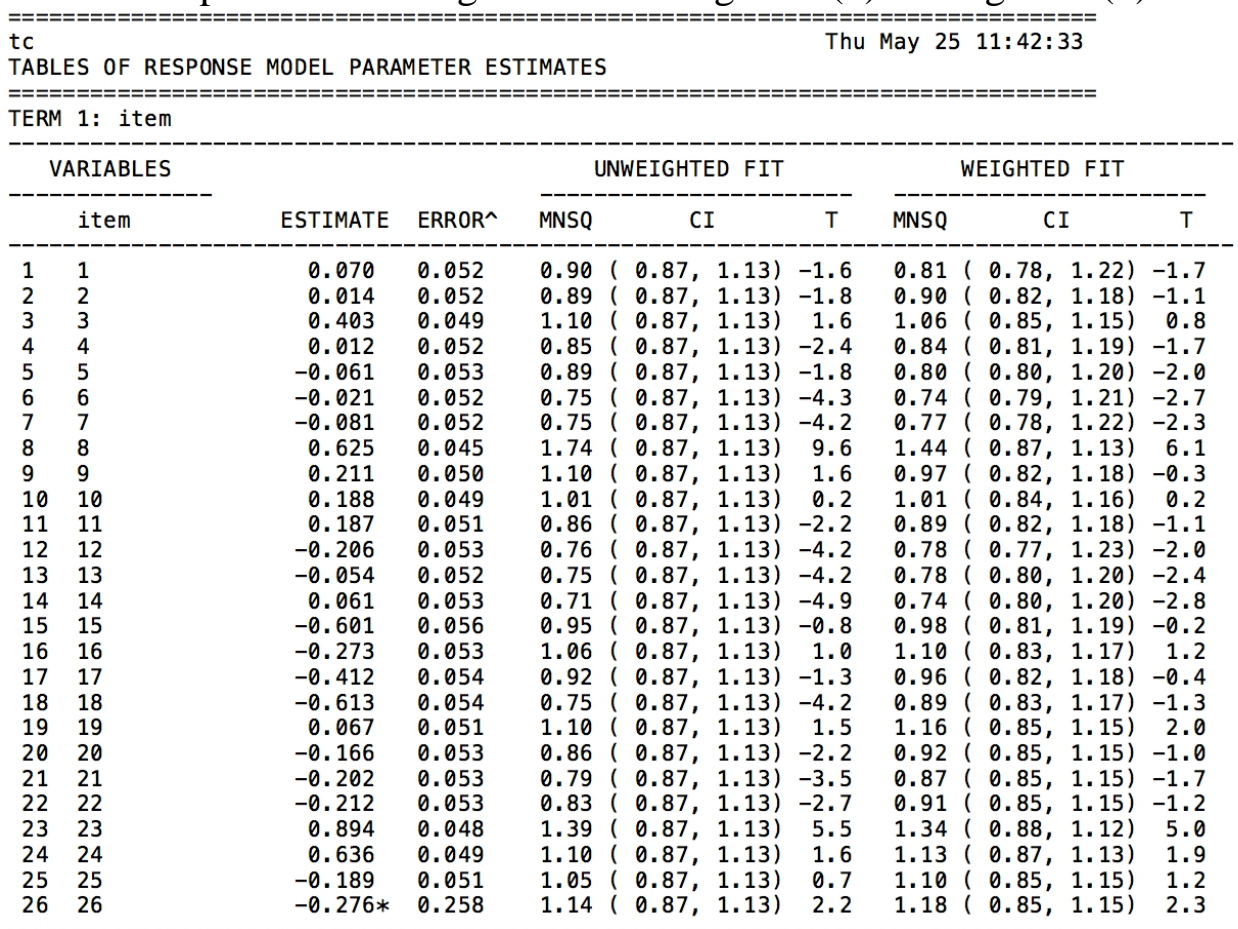

An asterisk next to a parameter estimate indicates that it is constrained Separation Reliability $=0.979$

Chi-square test of parameter equality $=1220.397, \mathrm{df}=25$, Sig Level $=0.000$

^ Quick standard errors have been used

Figure 1. Response model parameter estimates for the Partial Credit Model (1)

From figure 1(1), we can find that item 8 and 23 fit badly, namely, 'writing is addressing specific audiences' and 'length of a text' don't fit well, while figure 1(2) shows that the item*step parameters (i.e. the t-values) are generally small, the fit seems to be reasonable.

Then, from figure 2, one can find that participants generally tend to agree with most items concerning with conceptions of writing. Particularly, everyone agrees with items 12 and 15 to the largest extent, which shows that they highly accept the transfer effect of reading activities in facilitating the development of writing; also, they unanimously agree with the contribution of vocabulary to good texts. However, it can also be found that many participants disagree with item 23,8 , and 24 , which indicates that numerous participants ignore the importance of the length and punctuations of a text, and neglect the communicative function of writing. 


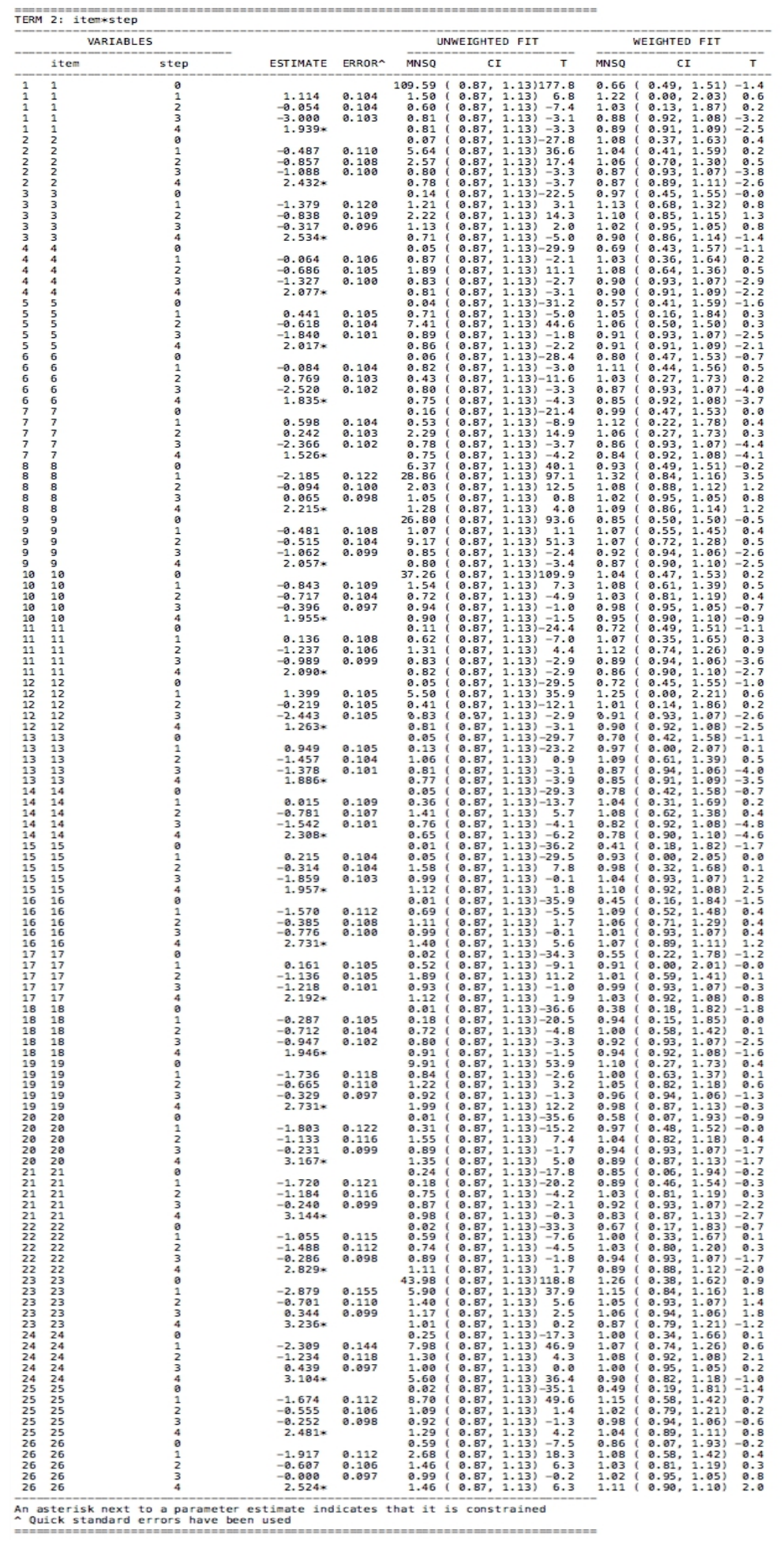

Figure 1. Response model parameter estimates for the Partial Credit Model (2) 


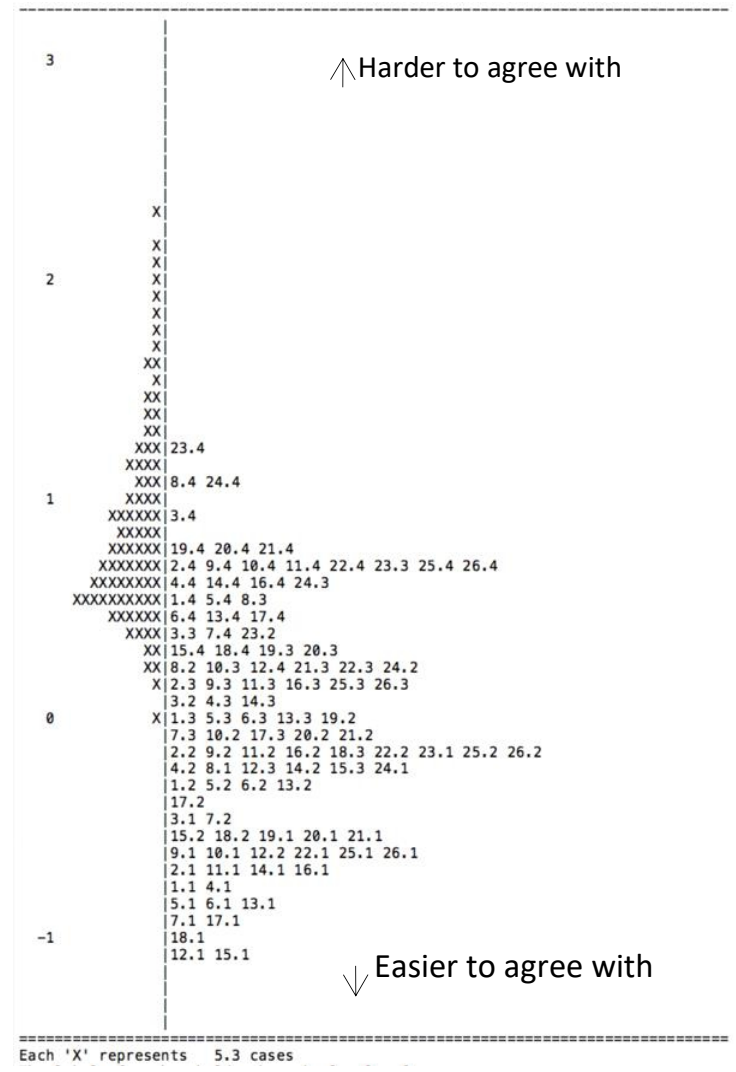

Figure 2. Item-Person Map: General distribution of participants' agreeability with conceptions of writing

\section{Agreeability with multifaceted concepts of writing}

In the current study, four constructs of teachers' conceptions of writing are included. It is, therefore, worth looking at participants' agreeability with each construct, from perspectives of their gender, school types, school levels, and school locations.

From Figure 3, it can found that both male and female participants mostly agree with writing as a linguistic and cultural activity, but do not fully agree with its social nature. From Figure 4, we can find that participants from private schools easily agree with writing as a linguistic and cultural activity, while those from public school are more unwilling to the social nature of writing. Figure 5 shows that teachers in junior and senior schools agree most with the linguistic nature of writing, while those teach in primary school can hardly agree with writing as a social activity. Figure 6 indicates that teachers work provincial capitals or county or town are inclined to accept writing as a linguistic act, while those from the rural areas are difficult to recognize writing as a social activity. 
Figure 3. Item-Person Map: Gender

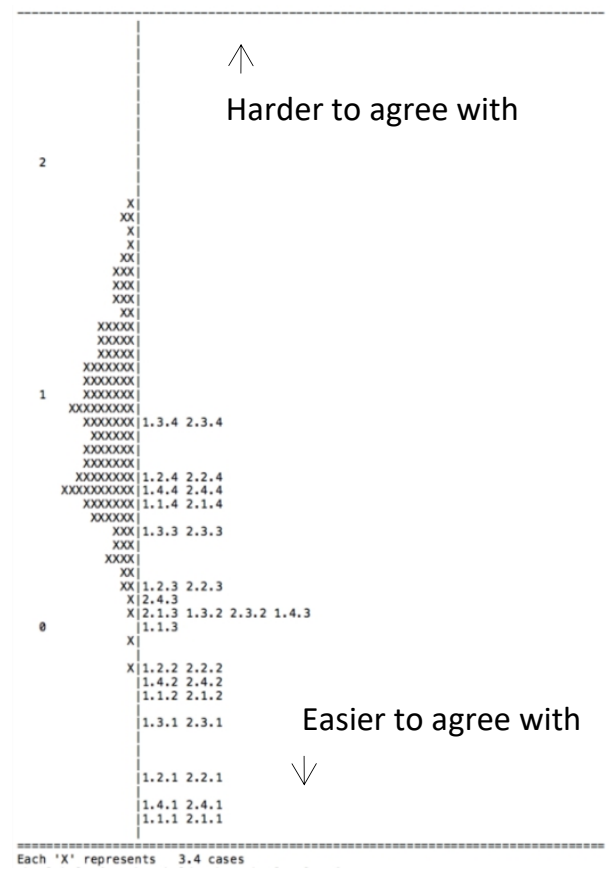

Figure 5. Item-Person Map: School level

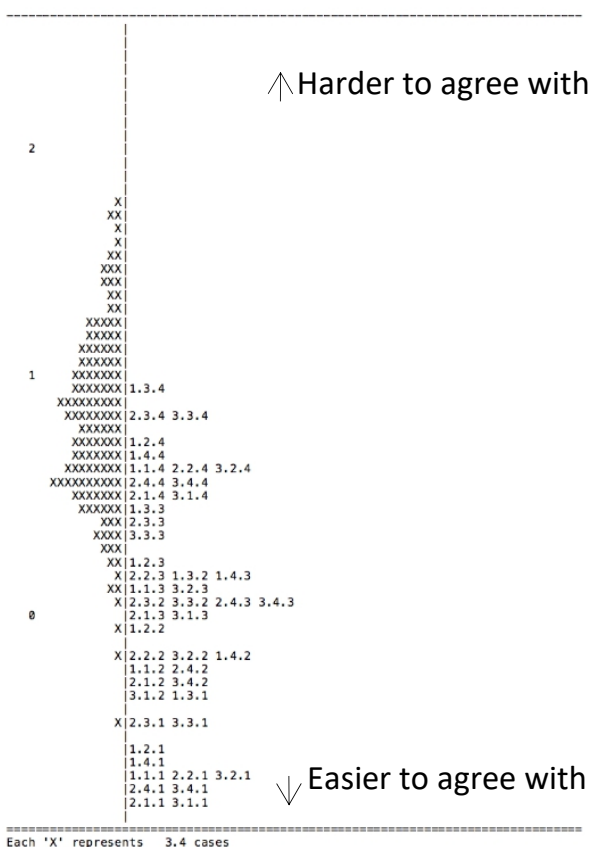

Figure 4. Item-Person Map: School type

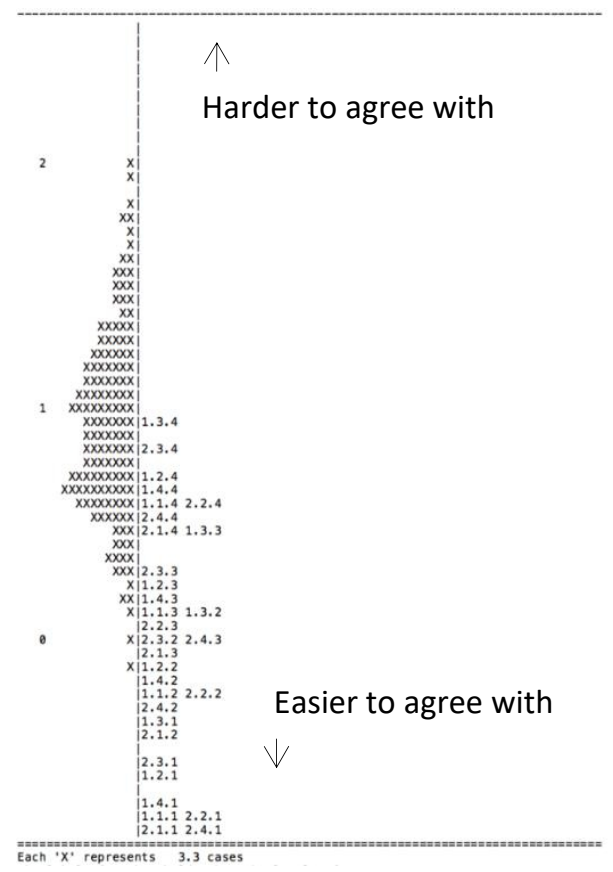

Figure 6. Item-Person Map: School location

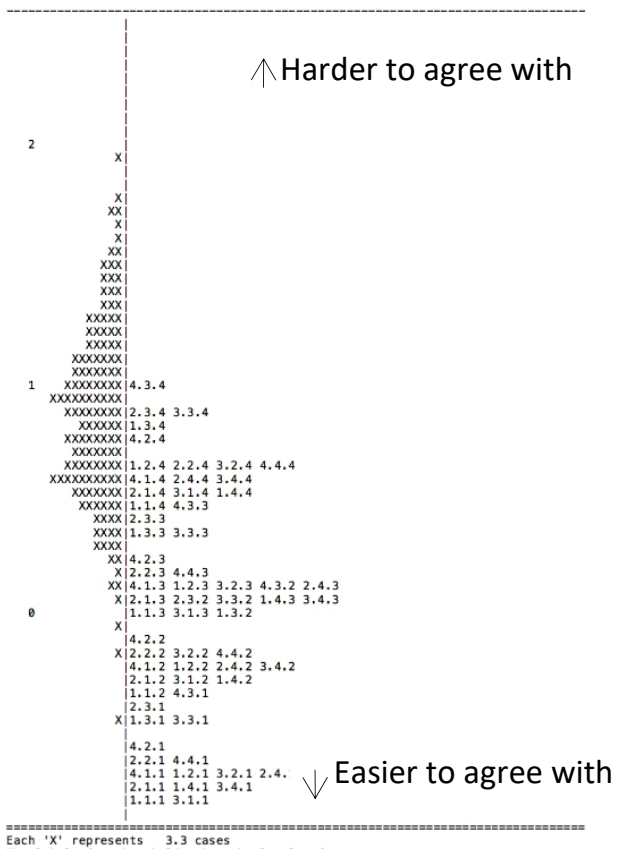




\section{Agreeability with multi-functions of writing}

From Figure 7, one can find that male participants easily agree with writing as creation, while female teachers are difficult to agree with its function in addressing specific audiences.

Figure 8 shows that participants from private schools easily agree with 'writing is of importance in one's career', while those from private school are more unwilling to recognize writing is addressing specific audiences.

Figure 9 indicates that teachers in senior schools agree most with writing as creation, while those teach in primary school can hardly agree with writing is addressing specific audiences.

Figure 10 shows that teachers work provincial capitals are inclined to accept writing as creation, while those from the rural areas are difficult to recognize writing is addressing specific audiences.

Figure 7. Item-Person Map: Gender Figure 8. Item-Person Map: School type
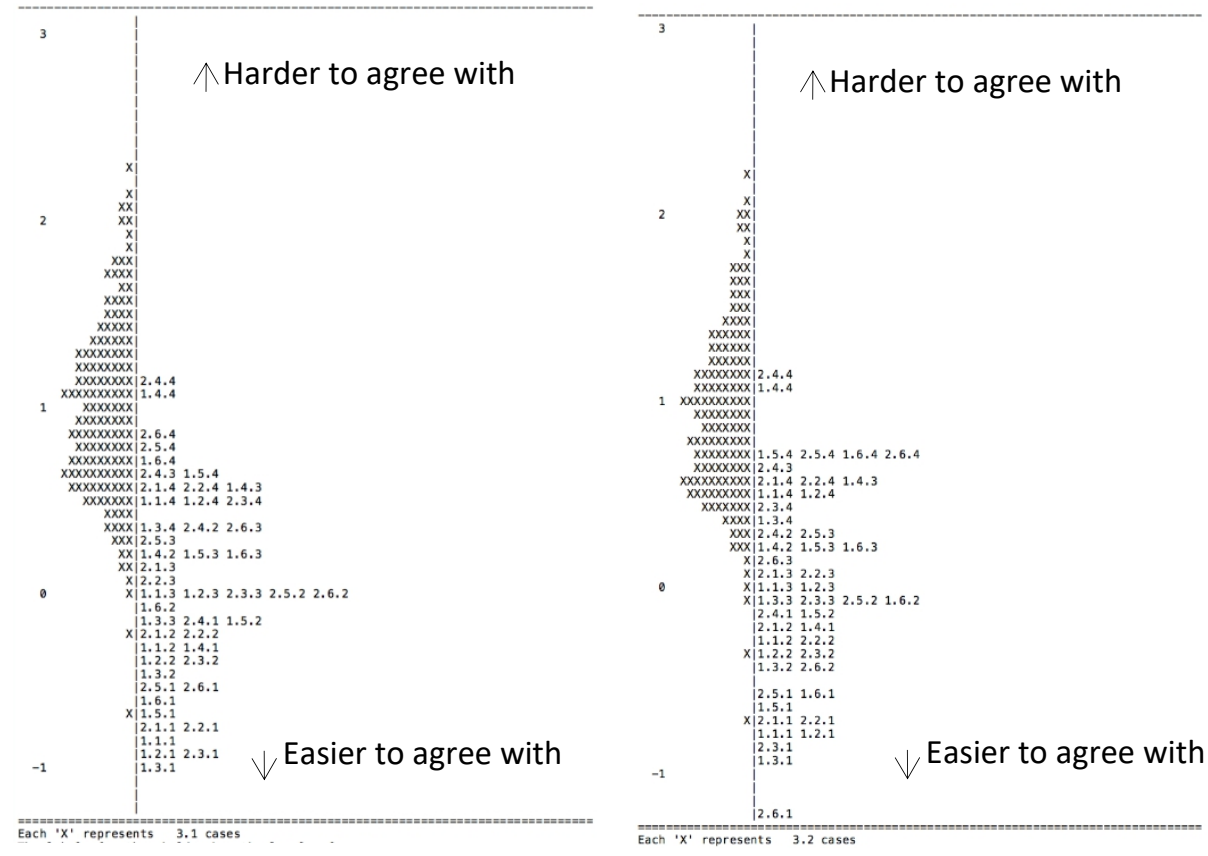
Figure 9. Item-Person Map: School level

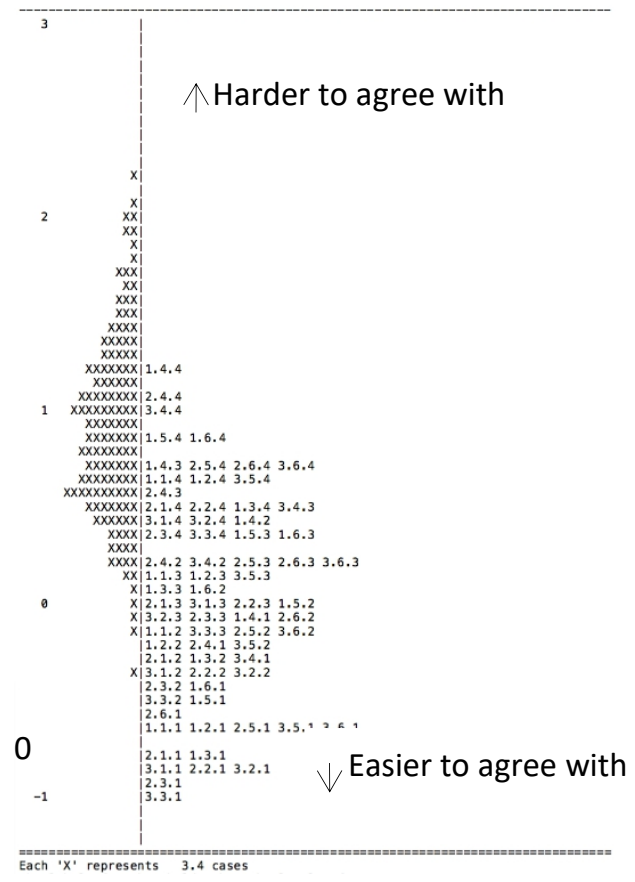

Figure 10. Item-Person Map: School location

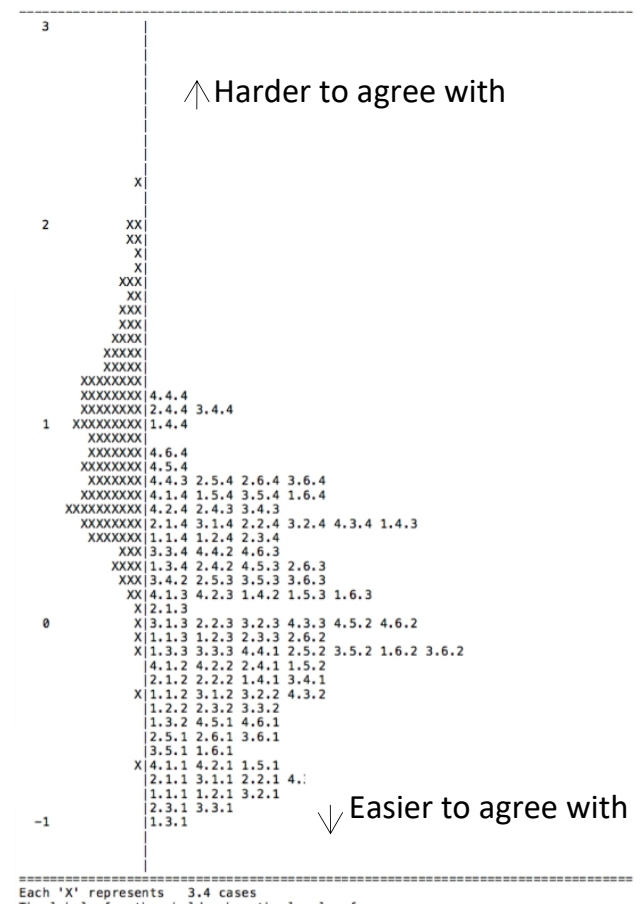

\section{Agreeability with development of writing}

From Figure 11, one can find that male and female participants mostly agree with the contribution of reading activities to the development of writing, while both male and female teachers are difficult to agree with the effect of speaking activities on writing development, and female participants are also unwilling to accept the effect of writing instruction on writing development.

Figure 12 shows that participants from private schools easily agree with the effect of reading activities on the development of writing, while teachers in both public and private schools are more unwilling to recognize the effect of speaking activities, and public school teachers also doubt the effect of writing instruction on developing writing.

Figure 13 indicates that teachers in senior schools agree most with the effect of reading activities, while teachers in primary and junior are uncertain with the effect of speaking activities on developing writing.

Figure 14 shows that teachers work provincial capitals are inclined to accept with the effect of reading activities, while those teach in cities are difficult to recognize the effect of speaking activities on developing writing. 
Figure 11. Item-Person Map: Gender

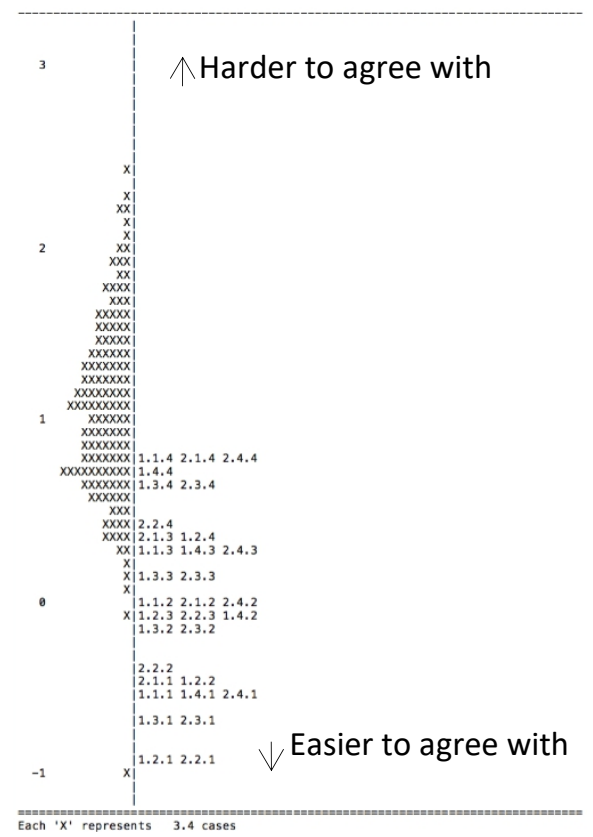

Figure 12. Item-Person Map: School type

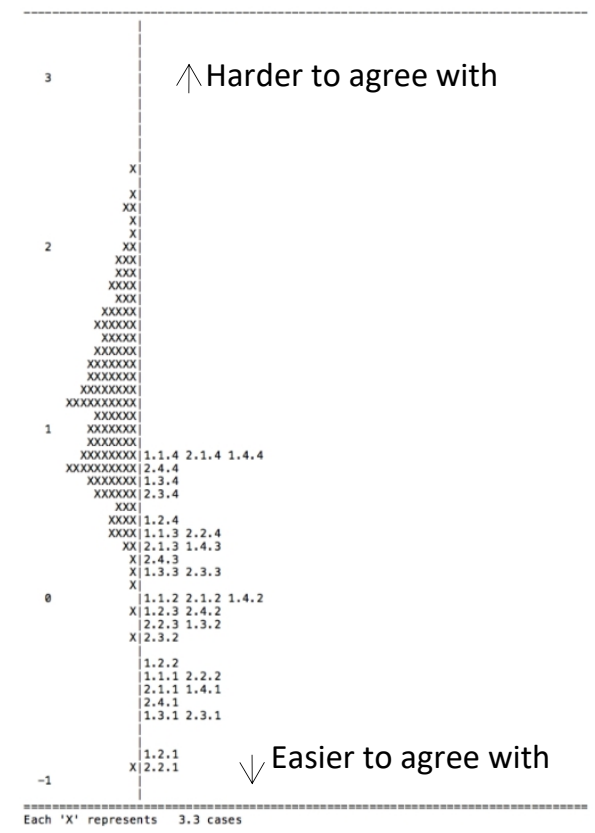

Figure 13. Item-Person Map: School level

Figure 14. Item-Person Map: School location
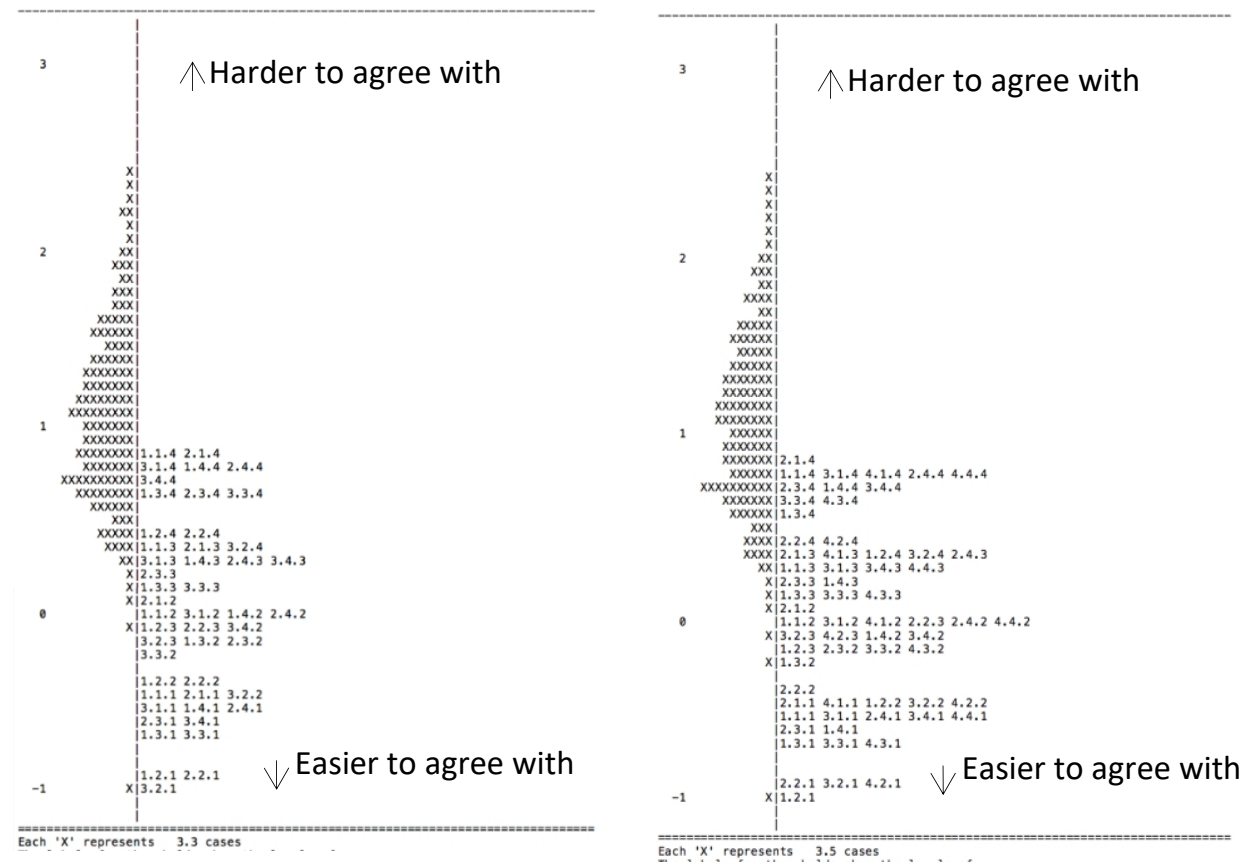


\section{Agreeability with basis of good writing}

From Figure 15, one can find that male and female participants mostly agree with vocabulary and grammar as features of good writing, while both genders doubt the length of a text as the basis of good writing.

Figure 16 shows that participants from public and private schools easily agree with vocabulary and content as basis of good writing, and teachers in private schools are aware of grammar, semantics and cohesive devices as basis of good writing, while teachers in both public and private schools are more unwilling to disagree length of a text as basis of good writing.

Figure 17 indicates that teachers in junior schools agree most with the vocabulary and content as basis of good writing, and senior school teachers accept vocabulary, grammar, semantics, structure of a paragraph, and handwriting as basis of good writing, teachers in primary, junior, and senior schools are unanimously apt to disagree with length and punctuation as basis of good writing.

Figure 18 shows that teachers work provincial capitals are inclined to accept with vocabulary, grammar, and semantics as basis of good writing, and those teach in cities recognize vocabulary, grammar, content, style, cohesive devices, structure of a paragraph, and punctuation as basis of good writing, while those in cities and villages are harder to accept length as basis of good text.

Figure 15. Item-Person Map: Gender Figure 16. Item-Person Map: School type
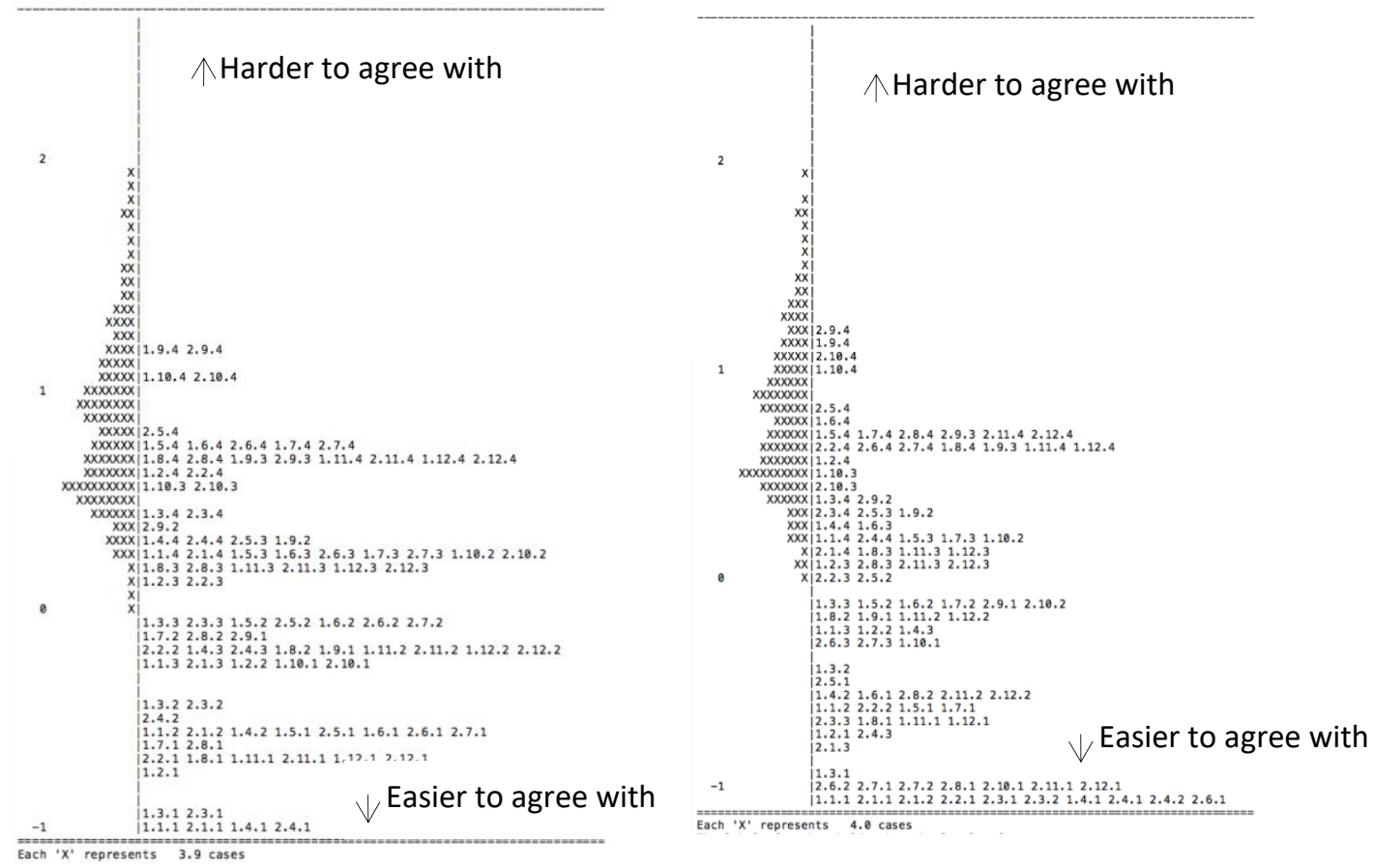
Figure 17. Item-Person Map: School level Figure 18. Item-Person Map: School location
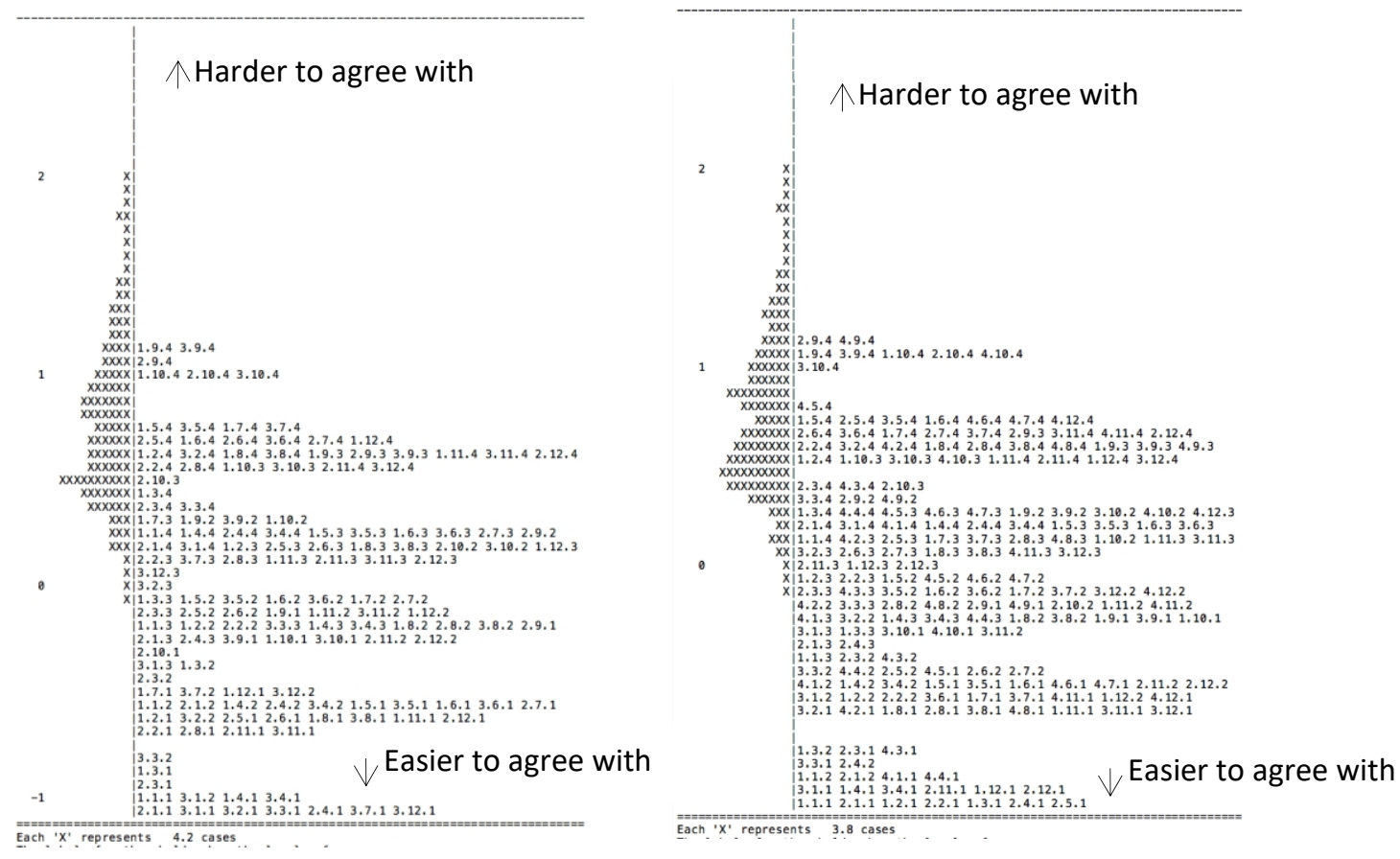

\section{Discussion and Conclusion}

This paper aimed to examine Chinese TEFL teachers' conceptions of writing, in particular, to find out their agreeability with multifaceted concepts of writing, multi-functions of writing, facilitators to the development of writing, and the basis of good writing.

Through various analyses, it is found that the reliability of the questionnaire is high. Also, results show that the partial credit model fits generally well on each construct regarding conceptions of writing. On the whole, participants generally tend to highly agree with the transfer effect of reading activities in facilitating the development of writing as well as the contribution of vocabulary to good texts. However, results also indicate that numerous participants ignore the importance of the length and punctuations of a text, and neglect the communicative function of writing.

With respect to the multifaceted natures of writing, either male and female participants, or teachers from public and private schools, or in primary, junior or senior schools, or in provincial capitals, cities, county or town, generally accept writing as a linguistic activity. Meanwhile, however, they unanimously neglect the social communicative nature of writing.

In terms of functions of writing, male teachers, senior school teachers and those in provincial capitals agree to the large extent with writing as creation, but interestingly, female teachers, primary school teachers, private 
school teachers, and village school teachers are harder to agree with writing is for addressing specific audiences.

With regard to development of writing, genders, private school teachers, senior school teachers, and provincial capital school teachers agree most with the transfer effect of reading activities on developing writing. However, genders, teachers in public and private schools, primary and junior school teachers, and teacher in cities doubt the effect of speaking activities on developing writing.

On the construct of good texts, genders, teachers in public and private schools, junior and senior school teachers, and those in provincial capital and cities generally agree with vocabulary as the basis for good writing, but interestingly, gender, school types, school levels, and teachers in cities and villages are harder to agree with the contribution of length to good text.

In conclusion, findings in this paper show that a Rasch Measurement objectively and reliably identified teachers' preferential conceptions of writing.

\section{Acknowledgements}

The author wishes to thank Prof. Dr. Gyöngyvér Molnár for her invaluable comments on an earlier draft of this article. The author would also like to thank the Stipendium Hungaricum Scholarship program and the China Scholarship Council for funding his Ph.D. studies.

\section{References}

Andrich, D. (1978). Rating formulation for ordered response categories. Psychometrika, (43), 561-573.

Coulmas, F. (1996). The Blackwell encyclopedia of writing systems. Oxford: Blackwell.

Crutchfield, J. (2015). Creative writing and performance in EFL teacher training: a preliminary case study. Scenario, 1, 1-34.

Ene, E., \& Mitrea, (2013). EFL Writing Teacher Training, Beliefs and Practices in Romania: A Tale of Adaptation. The European Journal of Applied Linguistics and TEFL, 2(2),117-138.

Farrell, T. S. (2006). Reflective practice in action: A case study of a writing teacher's reflections on practice. TESL Canada Journal, 23(2), 77-90.

Ferede, T., Melese, E., \& Tefera, E. (2012). A descriptive Survey on Teachers' Perception of EFL Writing and Their Practice of Teaching Writing: Preparatory Schools in Jimma Zone in Focus. Ethiopian Journal of Education and Sciences, 8(1), 29-52.

Flower, L., \& Hayes, J. R. (1981). A cognitive process theory of writing. College composition and communication, 32(4), 365-387. 
Fu, D., \& Matoush, M. (2012). Teachers' perceptions of English language writing instruction in China. In C. Bazerman, C. Dean, J. Early, K. Lunsford, S. Null, P. Rogers, \& A. Stansell (Eds.), International advances in writing research: Cultures, places, measures (pp. 23-39). South Carolina: Parlor Press.

Gelb, I. J. (1963). A study of writing. University of Chicago Press.

Hayes, J. (1996). A new framework for understanding cognition and effect in writing. In S. Ransdell, \& C. M. Levy (Eds.), Perspective on Writing: Research, Theory and Practice (pp.1-26). New Jersey: Lawrence Erlbaum Association publishers.

Hirvela, A., \& Belcher, D. (2007). Writing scholars as teacher educators: Exploring writing teacher education. Journal of Second Language Writing, 16(3), 125-128.

Hyland, K. (2002). Teaching and researching writing. London: Longman.

Hyland, K. (2015). Teaching and researching writing. New York: Longman. Khanalizadeh, B., \& Allami, H. (2012). The Impact of Teachers' Belief on EFL Writing Instruction. Theory and Practice in Language Studies, 2(2), 334342.

Koros, B. T., Indoshi, F. C., \& Okwach, T. (2013). Perception of teachers and students towards methods used in teaching and learning of English writing skills in secondary schools. International Journal of English Language and Linguistics Research, 1(1), 32-38.

Lee, I. (2010). Writing teacher education and teacher learning: Testimonies of four EFL teachers. Journal of Second Language Writing, 19(3), 143-157.

Lee, I. (2013). Becoming a writing teacher: Using "identity" as an analytic lens to understand EFL writing teachers' development. Journal of Second Language Writing, 22(3), 330-345.

Masters, G. N. (1982). A Rasch model for partial credit scoring. Psychometrika, (47), 149-74.

Melketo, T. A. (2012). Exploring tensions between English teachers' beliefs and practices in teaching writing. The International HETL Review, 2(11), 98114.

Min, H. T. (2013). A case study of an EFL writing teacher's belief and practice about written feedback. System, 41(3), 625-638.

Osterholm, K. (1986). Writing in the Native Language. In B. H. Wing, \& H. S., Lepke (Eds.), Listening, Reading, and Writing: Analysis and Application (p. 119). Northeast Conference on the Teaching of Foreign Languages.

Rasch, G. (1960). Probabilistic models for some intelligence and attainment tests. Chicago: University of Chicago Press.

Shulman, L. (1987). Knowledge and teaching: Foundations of the new reform. Harvard educational review, 57(1), 1-23. 
Sperling, M. (1996). Revising the writing-speaking connection: Challenges for research on writing and writing instruction. Review of Educational Research, 66, 53-86.

Tankó, G. (2005). Into Europe: Prepare for Modern English Exams: The Writing Handbook. TelekiLászló Foundation; British Council.

Wright, B. D, \& Master, G. N. (1982). Rating Scale Analysis: Rasch Measurement. Chicago: MESA Press.

Yang, L., \& Gao, S. (2013). Beliefs and practices of Chinese university teachers in EFL writing instruction. Language, Culture and Curriculum, 26(2), 128-145.

Yang, Y. I. (2015). An investigation of Chinese junior high school teachers' and students' attitudes towards EFL writing. International Journal of Research Studies in Education, 5(2), 59-75. 